\title{
Research on Construction and Application of Virtual Simulation Experimental Teaching Platform for Economic and Management Majors
}

Dawei Zhang*, Yong Wan

School of Economics and Management, Guangdong University of Petrochemical Technology, Maoming 525000, Guangdong, China.

Email: daweigongzuo@yeah.net

Funds: The authors acknowledge the financial support provided by the 2019 Philosophy and Social Sciences Planning Program of Maoming (2019QN02); The 2019 Science and Technology Planning Project of Maoming (2019392).

Abstract: With the rapid development of information technology, the country puts forward the development strategy of informatization, which requires the education field to be able to carry out the informatization construction of education management. As an important part of the information management of universities, the virtual simulation experiment teaching platform has practical and theoretical significance in the construction and application of individual professional virtual simulation experiment teaching. Based on the background, this paper takes the Economic and Management majors as the example to analyze the necessity of the construction and application of virtual simulation experiment teaching platform, and proposes the construction method and specific application status of virtual simulation experiment teaching platform, to carry out effective research on virtual simulation experiment teaching of economic and management.

Keywords: Economic and Management; Virtual Simulation Experiment Teaching; Platform Construction; Application Analysis

Virtual simulation experiment teaching refers to the establishment of a virtual experiment teaching system through new technologies such as computer technology and cloud computing technology. In order to provide more abundant practical experimental activities for teaching in colleges and universities. At present, with the help of virtual simulation experiment teaching platform, it has changed the teaching problem that emphasizes theory over practices in traditional economic management discipline teaching, and overcome the shortcomings in the traditional experimental practice teaching of management major to achieve the effect of optimizing economic management education resources, improving teaching quality, and promoting the development of teaching reform. From the standpoint of training talents in economics and management, the virtual simulation experiment teaching platform is used to create a teaching environment combining economics and reality for economics and management students, which greatly stimulates students' interest in learning and enhances the exploratory and innovative nature of students' professional learning. Eventually, a high-quality team of economic management personnel will be cultivated. Therefore, for the development of economic management, it is important and necessary to build a virtual simulation experiment teaching platform and use this information platform to carry out teaching activities.

\section{Demand for virtual simulation in the economic and management major}

\subsection{The software demand for virtual simulation in the economic management major}

Economic management involves two major categories of economics and management. With the development of the market economy system and the concept of innovative and entrepreneurial, it is also required to improve the practical innovation ability of economic management students in universities. In this regard, the virtual simulation experiment activities of the management category should involve supply chain management simulation experiment training,

Copyright (C) 2020 Dawei Zhang et al

doi: $10.18282 /$ le.v9i6.1325

This is an open-access article distributed under the terms of the Creative Commons Attribution Non-Commercial License

(http://creativecommons.org/licenses/by-nc/4.0/), which permits unrestricted non-commercial use, distribution, and reproduction in any medium, provided the original work is properly cited. 
financial management experiment training, ERP sand table confrontation simulation experiment.

\subsection{The hardware requirements of the economic management class for the virtual simulation platform}

Based on the current situation of economic management teaching, the software system required for its simulation experiments presents diversified development characteristics, and the number of students majoring in economics and management in major universities is considerable. Therefore, the entire virtual simulation teaching platform must be able to include a massive teaching database, fully equipped experimental facilities, and massive basic data. For this kind of virtual simulation teaching center, it needs to at least carry out simulation experiment teaching in five aspects of virtual simulation experiment application, experimental academic resources, online virtual laboratory, basic data, experimental facilities to achieve data sharing and intercommunication between systems through the central interactive library.

\section{Application status of virtual simulation experiment teaching platform}

The virtual simulation experiment teaching platform has been applied in the teaching of many subjects in universities, and has also driven many professional subjects to achieve innovative development. However, there are some deficiencies in the construction and application of teaching, which seriously restrict the quality and efficiency of personnel training in colleges and universities.

\subsection{The degree of combination of virtual and real in the virtual simulation experiment teaching platform is unclear}

The virtual simulation experimental teaching platform is essentially a teaching mode that realizes the combination of virtual and real, and complements each other. But in actual teaching applications, it is not possible to blindly pursue fully virtualized experimental operations. However, in practice, some professional experimental projects are operated on a virtual platform, which leads to the limitation of students' actual hands-on ability to find and solve problems. For example, the experimental activities of economics and management majors not only need to simulate the market environment, but also need to create a real team, and allow students learn team assistance and information sharing. However, by incorporating all experiments into a virtual teaching platform, students are prone to lose their ability to perceive real interpersonal relationships. Therefore, the degree of combination of reality and reality in the current virtual simulation experiment teaching platform is not clear and seriously restricts the quality of talent training.

\subsection{The degree of openness and sharing of virtual simulation experiment teaching platform is not comprehensive}

In fact, one of the characteristics of the virtual simulation experiment teaching platform is the high degree of resource sharing. But in the actual virtual experiment teaching activities of colleges and universities, it has not been able to take advantage of the platform's openness and sharing of information. For example, the sharing mechanism of the current virtual simulation experiment teaching platform has also established a singular sharing model. At the same time, each virtual simulation experiment teaching platform of various universities is isolated from each other, and the sharing development of content, method and mode cannot be realized.

\subsection{The teaching management team of the virtual simulation experiment teaching platform is not professional}

A reasonable talent team is a prerequisite for the orderly construction and application of the virtual simulation experiment teaching platform. Whether it is the development of virtual simulation experiment teaching platform software or the construction of new teaching resources, the optimization and upgrading of the system all require the support of professionals. But overall, the professional teaching team and technical management staff of the virtual simulation experiment teaching platform are in serious shortage. For example, the managers in the virtual simulation experiment classrooms in universities are mostly retired managers. They cannot maintain, manage, upgrade and optimize the virtual simulation experiment information system at all.

\section{Construction and application of virtual simulation experiment teaching platform for management majors}

Based on the new requirements for the construction of virtual simulation experiment teaching platforms for economic management majors mentioned above and the current status of the application of existing virtual simulation experiment teaching platforms, it can be seen that the virtual simulation teaching experiment platform must be based on 
the status quo of economic management teaching, to design new teaching methods and teaching management systems.

\subsection{Organization of virtual simulation experiment teaching platform for economic management majors}

Because economic management is a large professional direction, it involves multiple professional directions, and the application of its virtual simulation experimental teaching platform also requires teachers with different professional directions to carry out teaching guidance. Therefore, at present, it is necessary to form a teaching team of different majors and different courses for the virtual simulation experiment teaching platform, which is responsible for developing the experimental content and professional design. Secondly, it is necessary to provide a guidance group and laboratory technicians for the virtual experiment platform, so as to deal with the technical difficulties that may arise in the experiment process.

\subsection{Application method of economic management virtual simulation experiment teaching platform}

The virtual simulation experiment teaching platform for economic management majors needs to be matched with it in teaching applications. For example, the use of teamwork, independent exploration, project-driven and other methods to guide students to virtual simulation experiments, so that students can activate their hands and brains to carry out professional experimental training activities in economics and management, thereby mastering practical ability. For example, taking the practical teaching of marketing management electronic confrontation as an example, in virtual simulation experiment teaching, teachers can use role-playing methods to create a virtual practical situation for students, so that students can use the theoretical knowledge they have learned to carry out various market information analysis, product feature design and other operations.

\subsection{Assessment method of economic management virtual simulation experiment teaching platform}

Any kind of teaching activities needs to build a response teaching evaluation system, so that it can be clearly determined whether the quality of teaching meets the teaching goals. In the current virtual simulation experiment teaching activities of economic management, the assessment methods used are mainly the combination of individual performance assessment and team performance assessment. The personal performance evaluation indicators mainly include the completion of the experiment report and the students' speeches in the experiment preparation activities; the team performance evaluation takes into account the students' teamwork spirit and business decision-making ability. At the same time, it is also necessary to carry out the whole process of teaching assessment and evaluation and balanced scoring assessment on in-class, after-class and experimental operations, so as to determine the students' final results for the virtual simulation experimental course.

\section{Conclusion}

To sum up, no matter from the macroscopic college information teaching reform or economic management professional training target, it is imperative to build a virtual simulation experimental teaching platform. At present, in the construction of the virtual simulation experiment teaching platform for economic management majors, it is necessary to pay attention to the particularity of economic management experiment teaching so as to build a variety of virtual simulation experiment software including economics, management and other fields. It is also required the school to be able to build a teaching evaluation and evaluation mechanism in the virtual simulation experimental teaching platform of economics and management, and to carry out comprehensive evaluation management for the students' practical training courses. The last is to complete the exploration of the construction of the virtual simulation experimental teaching platform, and analyze the problems existing in the application of the actual virtual experimental teaching platform and future prospects.

\section{References}

1. Zheng H. Discussion on the construction of virtual simulation experiment platform for interdisciplinary financial management. Commercial Accounting 2020; 08: 112-115.

2. Guan S. Application status of virtual simulation experiment platform in experimental teaching. Journal of Changchun Education College 2018; 3411: 45-48.

3. Qiao P, Wu W. Construction of Master of Accounting (MPAcc) virtual simulation teaching experiment center. Laboratory Research and Exploration 2017; 3602: 168-172+213.

4. Xiong Y, Wang D, Zhao H, et al. Research on the application of economic management virtual simulation experiment teaching under the background of informationization_taking Hubei Institute of Technology as an example. Science and Technology Entrepreneurship Monthly 2017; 3010: 86-88. 